\title{
多孔質ガラス膜の複層化
}

\author{
矢沢哲夫・中道弘・江口清久・山口＼cjkstart修* \\ (大阪工業技術試験所, 563 池田市緑丘 1-8-31 \\ *日本セメント(株), 135 東京都江東区清澄 1-2-23
}

\section{Fabrication of Composite Porous Glass Membrane}

\author{
Tetsuo YAZAWA, Hiroshi NAKAMICHI, Kiyohisa EGUCHI and Osamu YAMAGUCHI* \\ $\left(\begin{array}{ccc}\text { Government Industrial Research Institute Osaka, 1-8-31 Midorigaoka, Ikeda-shi, Osaka } & 563 & \\ * \text { Central Research Laboratory Nihon Cement Co., Ltd., Kiyosumi 1-chome, Koto-ku, Tokyo } & 135\end{array}\right)$
}

Composite porous glass membranes were prepared by formation of porous glass layer of about 100 im thick on base porous ceramics with pore diameter of about $1.5 \mu \mathrm{m}$. The permeation rate of composite membrane obtained was about 14 times as large as the ordinary type of porous glass membrane and it was clear from the measurement of separation coefficient of hydrogen of hydrogen-nitrogen gas mixture that the membrane was defect-free. The conditions for obtaining defect-free membranes were as follows:

(1) The value of thermal expansion coefficient of mother glass baked on base ceramics was about $80-90 \%$ of that of base ceramics.

(2) The baking temperature was $780^{\circ}-810^{\circ} \mathrm{C}$.

(3) The composite membrane which was acid-treated was dried by the critical point drying method methanol.

[Received October 5, 1987; Accepted January 22, 1988]

Key-words : Porous glass, Composite membrane, Asymmetric membrane, Porous ceramics, Separation coefficient

\section{1. 緒 言}

近年，膜による分離プロセスが注目されているが，用 いられる分離膜の特性として, 分離係数, 透過速度がと もに大きなものが要求されている.そこで，機械的強度 が大きく，透過速度の大きな支持体の上に，分離係数の 大きな層を薄くコーティングした非対称膜を作る必要が ある。

支持体として多孔質セラミックスを選び，その上に分 離層として多孔質ガラスをコーティングする手法とし て, スパッタリング, ゾルゲル, 多孔質ガラス形成性母 体ガラスの塗布等がある1). しかし, 細孔径の制御され た多孔質ガラス層を得るためには，層の厚みは若干厚く はなるが, 多孔質ガラス形成性母体ガラスを塗布する手 法が, 最も適していると考えられる.これについては, 溶融したガラス中に多孔質セラミックスを浸漬し, 付着 したガラス層を研磨して複層化した多孔質ガラス膜を作
製したとの報告があるが2), この方法は, 研磨の過程も 複雑で, しかも, ガラス層の割れ及びセラミックス支持 体からのはく離がしばしば生ずる.ここでは, 多孔質が ラス形成性母体ガラス粉末を吹き付け塗布し, 次いで焼 成し, 更に分相処理及び酸処理を行った後, 乾燥して得 られる, 複層化した多孔質ガラス膜の作製法について述 ベる.

複層化した多孔質ガラス膜を作製する場合, 割れは, 次の三つの過程において生ずる。（1）多孔質セラミッ クスへの母体ガラスの焼き付け時, (2) 分相したガラ スの酸処理時, (3) 膜の乾燥時. (2) については, 江 口らの詳細な研究がある ${ }^{3)}$.ここでは，（1）及び（3） について検討する.

\section{2. 実 験}

\section{1 セラミックス支持体への焼き付け}

複層膜の作製過程を図 1 に示す。細孔径約 $1.5 \mu \mathrm{m}$ の

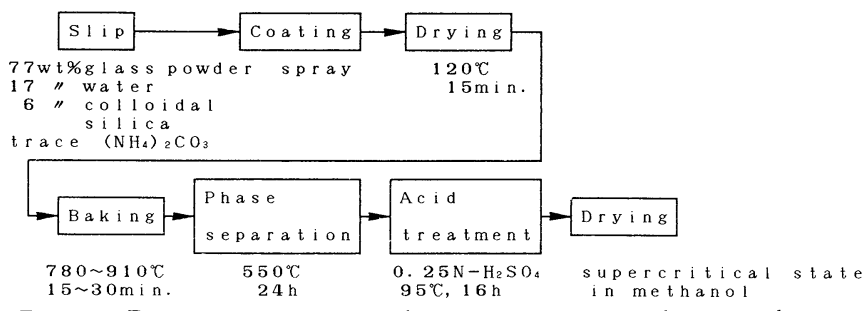

Fig. 1. Preparation process of composite porous glass membrane. 
Table 1. Composition and thermal expansion coefficient of base ceramics and occurrence of cracks on baking of mother glass.

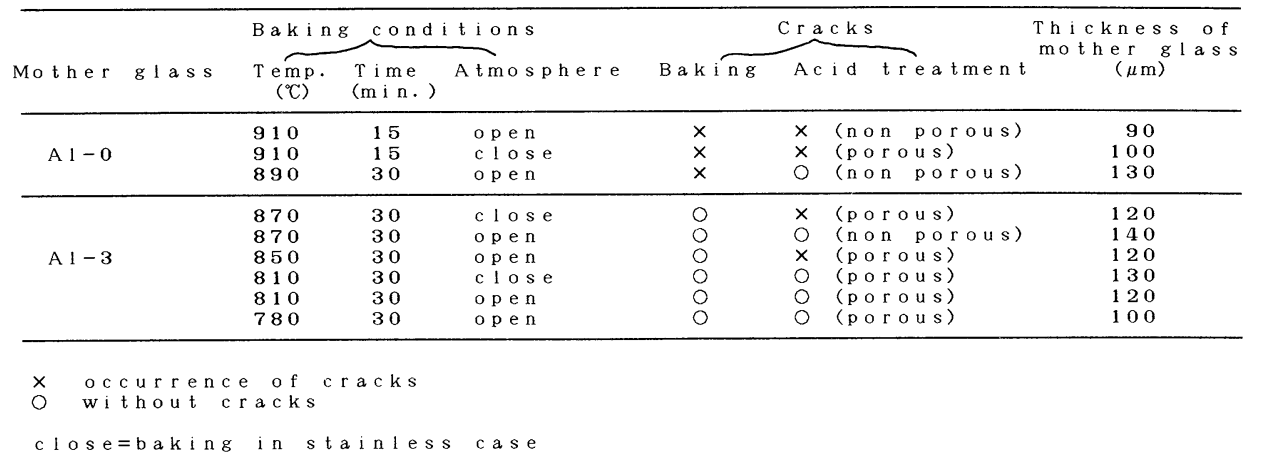

Table 2. Thermal expansion coefficient softening temperature and glass transition temperature of mother glass.

\begin{tabular}{llcc}
\hline Mother glass & $\begin{array}{c}\text { Expansion } \\
\text { coefficient } \\
\left(\text { deg }^{-1}\right)\end{array}$ & $\begin{array}{c}\text { Softening } \\
\text { temperature }\end{array}$ & $\begin{array}{c}\text { Giass transition } \\
\text { temperature } \\
\left({ }^{\circ} \mathrm{C}\right)\end{array}$ \\
\hline A $1-0$ & $55 \times 10^{-7}$ & 610 & 510 \\
A $1-3$ & 46 & 585 & 490 \\
\hline
\end{tabular}

Composition of mother g1 ass (wt\%)

$\mathrm{Al}-0: 62.5 \mathrm{~S} \mathrm{i} \mathrm{O}_{2} \cdot 28.3 \mathrm{~B}_{2} \mathrm{O}_{3} \cdot 9.3 \mathrm{Na}_{2} \mathrm{O}$

$\mathrm{Al}-3: 62.5 \mathrm{SiO} \cdot 27.3 \mathrm{~B}_{2} \mathrm{O}_{3} \cdot 7.2 \mathrm{Na}_{2} \mathrm{O} \cdot 3 \cdot 0 \mathrm{Al}_{2} \mathrm{O}_{3}$

多孔質セラミックス管 (内径 $8 \mathrm{~mm}$, 外径 $10 \mathrm{~mm}$ ) に重 量組成亡して, 母体ガラス粉 $77 \%$, 水 $17 \%$, コロイダ ルシリカ（日産化学製スノーテックス 20）6\% 及び微量 の炭酸アンモニウムを含んだスリップをエアー式のスプ レーで塗布した. 母体ガラスは, 88〜 560 $\mu \mathrm{m}$ 程度に粗 粉砕し, ガラス粉の凝集を防ぐため電解質として, 焼成 しても後に残らない炭酸アンモニウムを使用した.また, コロイダルシリカは，増粘剤として用いた．支持体とな る多孔質セラミックスの組成及び熱膨張係数を表 1 に, 焼き付けるガラスの組成, 熱膨張係数, 軟化点及びガラ ス転移点を表 2 に示す. 焼き付け温度は $780^{\circ} \sim 910^{\circ} \mathrm{C}$ と した. 焼き付け時の雾囲気は, 炉内でそのまま試料を焼 成する解放系と, ステンレス製の箱のなかで焼成する密 閉系とした。

\section{2 複層膜の乾燥}

多孔質セラミックスに焼き付けた母体ガラスを酸処理 した後, 酸処理溶液をメタノールによって置換した。す なわち, 酸処理した試料を直ちに, メ夕ノールに浸漬し て細孔内の水をメタノールと置換して, その後徐々に乾 燥させることにした. 更に, 次の方法によっても膜の乾 操を試みた。酸処理の終わった多孔質ガラス膜を, メ夕 ノールに 24 時間浸漬し, 次にオートクレーブ中で, メ タノールが超臨界状態になる $300^{\circ} \mathrm{C}, 8 \mathrm{MPa}$ (メタ)ー ルの臨界温度, 圧力は $\left.240.5^{\circ} \mathrm{C}, 7.89 \mathrm{MPa}^{4)}\right)$ にした。 30 分間超臨界状態を保った後 30 分間かけてオートク レーブ内の圧力を大気圧まで下げ, 更に室温まで冷却し て乾燥を終了した.

\section{3 複層膜の細孔特性の測定}

複層膜の多孔質ガラスの部分だけを搔き取り細孔特性 を測定した。测定は，Carlo Erba製の窒素吸着装置 Sorptomatic 1800 型を用いた。細孔容積, 細孔分布は, 等温脱着曲線から Kelvin 式に円筒モデルを仮定した BJH 法によって求めた ${ }^{5 !}$.

\section{4 複層膜の分離特性の評価}

分離膜モジュールを図 2 に，実験装置の概略を図 3 に 示す. 図 2 に示すように長さ $16 \mathrm{~cm}$, 外径 $3.5 \mathrm{~cm}$ のア クリル樹脂管に隔壁を設け, 外径 $10 \mathrm{~mm}$, 内径 $8 \mathrm{~mm}$ の 複層化した多孔質ガラス膜を接続したものを膜モジュー ルとした。供給気体は, 図 3 中の矢印で示したように多

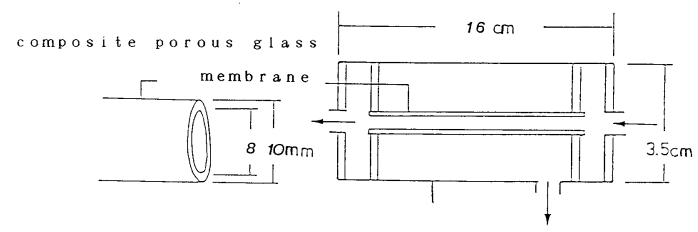

Fig. 2. Membrane module of composite porous glass membrane.

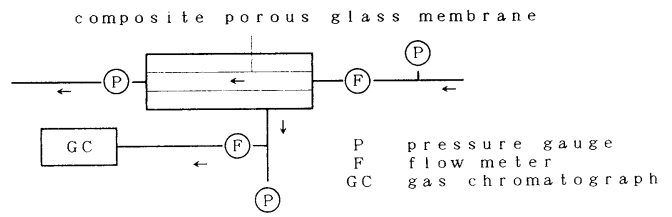

Fig. 3. Schematic diagram of apparatus for gas separation. 
孔質ガラス膜の内部を流れ，透過気体は，多孔質ガラス 膜の外部から流量計, 真空計, 真空ポンプを経て流れる ようにした。膜モジュールの膜面積は， $18 \mathrm{~cm}^{2)}$, 供給 気体の絶対圧は，0.12 0.30 MPa とした。

分離係数の測定には $50-50 \mathrm{vol} \%$ 組成の $\mathrm{H}_{2}-\mathrm{N}_{2}$ 混合 気体を用いた。気体の透過速度の測定には, Hastings 製の質量流量計 NALL-1 K 型, 気体の成分分析には柳 本製作所製ガスクロマトグラフ G-18 型を用いた。非透 過側の水素濃度としては供給気体の水素濃度と非透過側 の端末で採取した水素濃度の算術平均値を用いた ${ }^{6)}$.

\section{3. 結果及び考察}

\section{1 セラミックス支持体への焼き付け}

表 3 に焼き付け温度, 雾囲気, 焼き付け時の割れ, 酸 処理時の割れ，焼き付け層の厚みを示す. Al-0 の組成 のガラスの焼き付け温度は, $\mathrm{Al}-3$ の場合よりも $100^{\circ} \mathrm{C}$ 程度高くする必要があるが，これは表 2 から分かるよう に軟化点, ガラス転移点が Al-0 のガラスの方が高いか らである，Al-0の組成のガラスは，焼き付け時にすべ て割れが生じる。これは，焼き付け時に生じたクリス卜 バライトの $\alpha \rightarrow \beta$ 転移による体積変化によるためと思わ れる7). 事実 Al-0 のガラス粉にコロイダルシリカを加 えて棒状試料を作製して熱膨張を調べると $160^{\circ} \sim 270^{\circ} \mathrm{C}$ 付近でクリストバライトによる異常膨張が見られる（図 4)。またクリストバライトは，X 線回折からも観察さ れる.

焼き付けるガラスを Al-3 として，セラミックス支持 体の膨張係数を $45 \sim 80 \times 10^{-7} \mathrm{deg}^{-1}$ まで変化させて, 割れの状況を調べたのが表 1 である，七ラミックスは， 日本化学陶業製及び日本セメント製のものを用いた。 七 ラミックス支持体の膨張係数が， $58 \times 10^{-7} \mathrm{deg}^{-1}$ 及び $65 \times 10^{-7} \mathrm{deg}^{-1}$ のものの割れがほとんどない.Al-3 の 膨張係数が， $46 \times 10^{-7} \mathrm{deg}^{-1}$ なので 10 20\% 程度焼き 付けるガラスの膨張係数が小さいと割れがなくなる.

一般に, 釉がけの場合, 生地となるセラミックスと釉 との間に十分な密着を生ずるためには，室温まで泠却し た後, 釉が圧縮状態にあることが望ましい ${ }^{8)}$. 釉に引つ

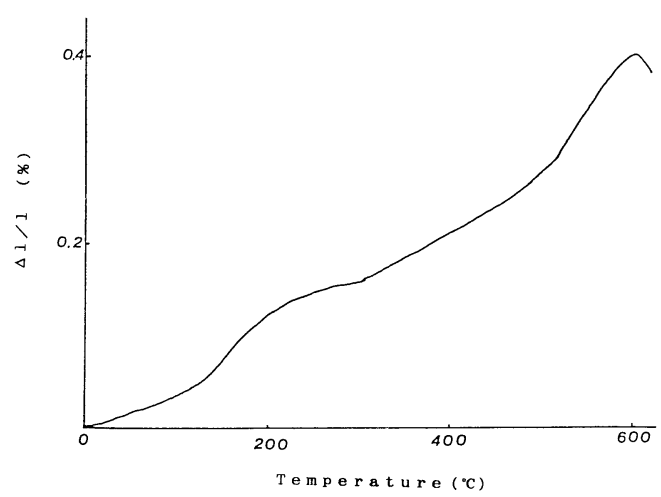

Fig. 4. Thermal expansion curve of rod prepared by sintering of Al-0 glass powder with colloidal silica.

張り応力が発生すると，ひびがはいりやすい。ひび割れ は引っ張り応力が増大して釉の引っ張り強さを超えたと きに起こる，もし，逆に釉が圧縮応力のもとにあるとす ると，この種の破壞は起こらない，かなりの応力の場合 だけ圧縮応力のもとでおこる逆破壊，すなわちシーベリ ングが起こる. 釉掛け温度 $T_{0}$, 室温 $T$, 釉のヤング率 $Y$, ポアッソン比 $\sigma$, 線膨張率 $\alpha_{0}$, 七ラミックス支持体の 線膨張率 $\alpha_{1}$, 釉のついた円筒の断面積 $A_{0}$, セラミック 又支持体の断面積 $A_{1}$ とすれば, 応力 $f$ に関して (1) 式が成立する ${ }^{7}$.

$$
f=(Y /(1-\sigma))\left(T_{0}-T\right)\left(\alpha_{1}-\alpha_{0}\right)\left(A_{1} / A_{0}\right)
$$

焼き付けガラスのヤング率を $57 \mathrm{GPa}$ ，ポアッンン比を 0.22 とすれば9), 割れのない場合のガラス層の圧縮応力 は25〜 $57 \mathrm{MPa}$ となる. 以後の実験では，焼き付ける セラミックス支持体を C-6 とした.

\section{2 酸処理}

焼き付け温度を $870^{\circ} \mathrm{C}$ 以上, 焼き付け雾囲気を解放 系にすると酸処理しても多孔質ガラスとはならない。雾

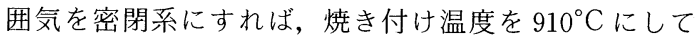
も多孔質ガラスとなる．解放系で多孔質ガラスとならな いのは，ホウ酸の揮発によってガラス表面にシリカ層が 形成され，これが酸処理の際に不働体として働いている ためと考えられる ${ }^{10)} .870^{\circ} \mathrm{C}$, 密閉系で焼き付けると酸

Table 3. Occurrence of cracks on baking and acid treatment and thickness of mother glass baked on base ceramics.

\begin{tabular}{|c|c|c|c|c|c|c|}
\hline Base ceramics & $\begin{array}{l}\text { Composi } \\
\mathrm{SiO}_{2}\end{array}$ & $\begin{array}{l}\text { t i on }(w t \%) \\
\mathrm{Al}_{2} \mathrm{O}_{3}\end{array}$ & $\begin{array}{c}\text { Expansion coeffic ient } \\
\left(\mathrm{deg}^{-1}\right)\end{array}$ & $\begin{array}{l}\text { C racks } \\
\text { of mothe }\end{array}$ & $\begin{array}{l}\text { on } \\
\text { er }\end{array}$ & $\begin{array}{l}\text { baking } \\
\text { glass }\end{array}$ \\
\hline $\mathrm{C}-1$ & 51 & 43 & $42 \times 10^{-7}$ & & $\times$ & \\
\hline $\mathrm{C}-2$ & 49 & 47 & 45 & & $\hat{x}$ & \\
\hline$C-3$ & 41 & 55 & 49 & & $x$ & \\
\hline$C-4$ & 28 & 69 & 50 & & $\hat{x}$ & \\
\hline$C-5$ & 7 & 92 & 58 & & 0 & \\
\hline$C-6$ & 10 & 90 & 65 & & 0 & \\
\hline $\mathrm{C}-7$ & 0 & 100 & 80 & & $x$ & \\
\hline
\end{tabular}

$\mathrm{C}-1,-2,-3,-4,-5,-7=\mathrm{Produced}$ by Nippon Kagaku Togyo Co., LTD.

$\mathrm{C}-\mathbf{6}=\mathrm{Produced}$ by $\mathrm{N}$ i hon $\mathrm{C}$ ement Co., LTD.

$\times \quad$ occurrence of cracks

without cracks 
処理後多孔質ガラスになりしかも割れが生じないが, 解 放系では多孔質ガラスとならない。また， $850^{\circ} \mathrm{C}$ の解放 系では，多孔化はするが割れが生じる。割れが生じるの は，まだこの温度でもシリカ層が部分的に存在していて， 酸処理時に多孔化する部分とそうでない部分での伸びの 差によるためと考えられる ${ }^{10)}$. 焼き付け温度を $810^{\circ} \mathrm{C}$ 以 下にすると解放系，密閉系のいかんにかかわらず割れの ない多孔質がラスの複層膜が得られる。

\section{3 膜の乾燥}

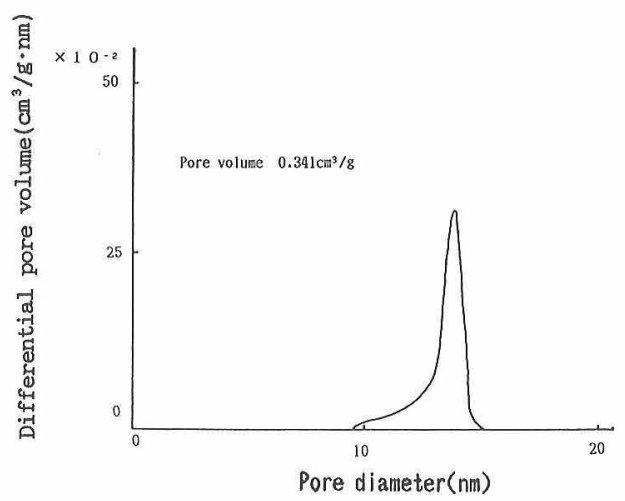

Fig. 5. Pore size distribution curve of porous glass layer of composite porous glass membrane.

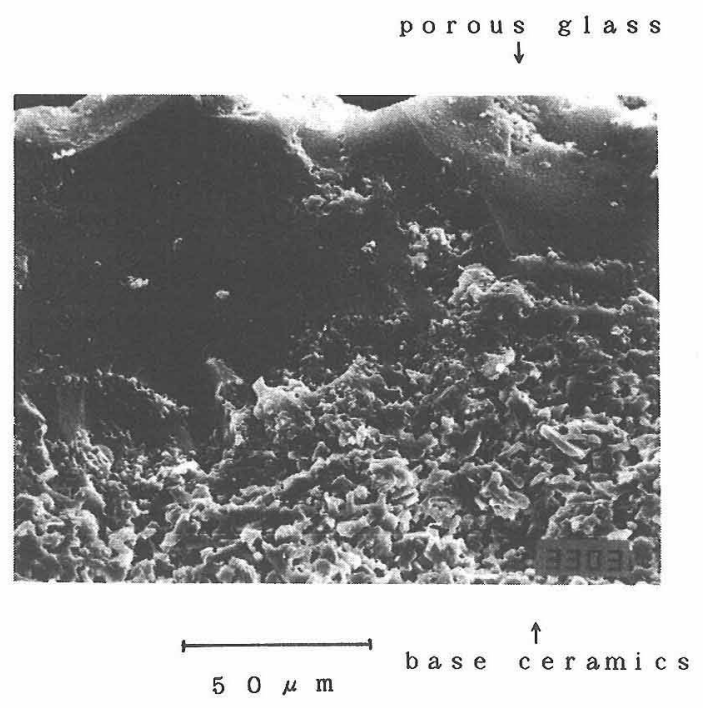

Fig.6. SEM photograph of joint region of composite porous glass membrane.
ところで, 割れが生じないと言っても, 酸処理溶液中 からそのまま乾燥させたのでは乾燥過程で割れが発生す る.この原因としては，急激な乾燥によって，収縮時に 生じる細孔中の液体の表面張力による応力が考えられる ので，水上の置換性が良く，かつ表面張力が水の $1 / 3$ 程 度であるメ夕ノール中 (水, メ夕ノールの表面張力 7.28 , $\left.2.25 \times 10^{-2} \mathrm{~N} / \mathrm{m}, 20^{\circ} \mathrm{C}\right)$ に浸漬して，それから徐々に 乾燥することを武みた。割れは，かなり少なくなったも のの，目視でも，なお割れが観察できた。

そこで，電子顕微鏡で生物試料を観察するために汎用 されている臨界点乾燥法を行った ${ }^{11 !}$ 。これは, 系を気液 界面のない超臨界状態に保持し，その後ブロ一・オフす れば，表面張力による応力の発生なしに試料を乾燥でき る方法である，この方法によって多孔質がラスを，多孔 質セラミックスの上に $100 \mu \mathrm{m}$ 程度の厚みでコーティン グすることができた。こうして得られた複層膜の多孔質 ガラス層にあたる部分の細孔分布を図 5 に示す。また， 多孔質ガラスと多孔質セラミックスとの接着面の電子顕 微鏡写真を図 6 に示すが，両者は良く接着していること が分かる。

\section{4 複層膜の分離特性}

窒素-水素混合気体についての複層膜の気体透過能を 表 4 に示す. 比較として同程度の細孔容積を持つ多孔質 ガラス膜単独の透過速度を併記したが，透過速度は，約 14 倍大きくなっており複層化すれば膜の透過性能は一 段と向上することが分かる．また，水素の分離係数も多 孔質ガラス膜単独の場合とさほぼ変わっていないことか ら得られた複層膜は，ピンホールなどのない無欠陥な膜 と考えられる.

\section{4. 総 括}

（1）多孔質アルミナの支持体の上に多孔質ガラスを $100 \mu \mathrm{m}$ 前後の厚みで焼き付けることができる.

（2）焼き付け温度は， $780^{\circ} \sim 810^{\circ} \mathrm{C}$ 程度にするのが 好ましい。

（3）焼き付ける母体ガラスの熱膨張率は，セラミッ クス支持体のそれよりも 10～20\% 程度小さいことが必 要である。

（4）酸処理後の膜の乾燥は，水との置換性の良いメ タノールで含浸させ，その後臨界点乾燥法を用いる必要 がある.

Table 4. Comparison of permeation characteristics of porous glass membrane and composite porous glass membrane.

\begin{tabular}{lccc}
\hline Membrane & $\begin{array}{c}\text { Permeation rate } \\
\left(\mathrm{m}^{3}(\mathrm{STP}) \cdot \mathrm{m}^{-2} \cdot \mathrm{s}^{-1} \cdot \mathrm{Pa} \mathrm{a}^{-1}\right)\end{array}$ & Separation coefficient of hydrogen \\
\hline $\begin{array}{l}\text { Porous glass } \\
\text { membrane }\end{array}$ & $5 \times 10^{-9}$ & 3.06 \\
$\begin{array}{l}\text { Composite porous } \\
\text { glass membrane }\end{array}$ & 68 & 2.73 \\
\hline
\end{tabular}


（5）得られた複層膜は, 気体の透過速度が, 非常に 大きくかつピンホールなどのない無欠陥なものである.

記号

$\begin{array}{lll}A_{0} & \text { 釉のついた円筒の断面積 } & \mathrm{m}^{2} \\ A_{1} & \text { セラミックス支持体の断面積 } & \mathrm{m}^{2} \\ f & \text { 応力 } & \mathrm{Pa} \\ T & \text { 室温 } & { }^{\circ} \mathrm{C} \\ T_{0} & \text { 釉掛けの温度 } & { }^{\circ} \mathrm{C} \\ Y & \text { ヤング率 } & \mathrm{Pa} \\ \alpha_{0} & \text { 釉の線膨張係数 } & \mathrm{deg}^{-1} \\ \alpha_{1} & \text { セラミックス支持体の線膨張係数 } & \mathrm{deg}^{-1} \\ \sigma & \text { ポアッソン比 } & \end{array}$

\section{文献}

1) 和佐清隆, セラミックス, 21, 119 (1986).

2) J.P. Monocouyoux, J.P. Faurie and R. Kohlmuller, Verres Réfract., 31, 405 (1977).

3）江口清久, 大阪工業技術試験所報告, No. 355，3-30 (1979).

4）“化学便覧一基礎編 II”, 丸善（1984）p. 109.

5) E. P. Barret, L. G. Joyner and P. P. Halenda, J. Am. Chem. Soc., 73, 373 (1951).

6) 矢沢哲夫, 田中博史, 江口清久, 日化, 201 (1986).

7) W. D. Kingery, H. K. Bowen and D.R. Uhlmann, "Introduction to Ceramics", John Wiley \& Sons, Inc. (1976) p. 591.

8) ibid., pp. 607-611.

9）兽我直弘, “ガラスハンドブック”, 作花済夫, 境野照雄, 高橋克明編, 朝倉書店 (1975) p. 659 .

10）江口清久, 大阪工業技術試験所報告 No. 355, 69-73(1979).

11）永谷 隆, “走査電子顕微鏡——基礎と応用一”, 日本 電子顕微鏡学会関東支部編, 共立出版 (1976) pp. 96-99. 